\title{
OPTIMALISASI STRATEGI POLMAS GUNA MENDUKUNG PENERAPAN PROTOKOL KESEHATAN SELAMA PANDEMI COVID-19 DALAM RANGKA TERWUJUDNYA SITUASI KAMTIBMAS YANG KONDUSIF
}

\author{
Kodrat Alam, \\ Asep Dadan Kusumah \\ Universitas Wiralodra \\ Email : amuksamudrajustitia@gmail.com, \\ asepdadankusumah@gmail.com
}

\begin{abstract}
Many people have not implemented health protocols in carrying out their daily activities is a special phenomenon that deserves serious attention from various parties, including elements of the Police in it. This is possible considering the implementation of the main functions and duties of the Police in the field of Kamtibmas which can reach up to the smallest units in society through the implementation of the Community Policing (Polmas) strategy. Polmas through adjustments to the implementation of the main functions and duties of Bhabinkamtibmas as Community Policing Bearers (Polmas) which are oriented towards achieving increased public awareness and compliance in implementing health protocols. In this concept, the researcher conducted research using normative juridical methods. This juridical approach is because this research analyzes existing legal aspects, and is normative because this research focuses more on the analysis of existing laws and regulations and other regulations, using secondary data, namely scientific references or other scientific writings as study material that can support the completeness of this scientific work Specifically regarding adjustments to the implementation of the main functions and duties of Bhabinkamtibmas as Community Policing Carriers (Polmas) which are oriented towards achieving increased public awareness and compliance in implementing health protocols, the implementation is carried out with the support and involvement of the Police and Community Partnership Forum (FKPM).
\end{abstract}

Keywords: Community Police, Kamtibmas, Health Protocol, Covid 19.

\section{PENDAHULUAN}

Kepatuhan masyarakat dalam menerapkan protokol kesehatan selama berlangsungnya pandemi Covid-19 hingga kini belum membuahkan hasil sebagaimana yang diharapkan. Hal ini terbukti dengan semakin meluasnya tingkat penyebaran virus Corona di seluruh Indonesia.

Minimnya ketersediaan informasi dan sosialisasi mengenai pentingnya penerapan protokol kesehatan seringkali menjadi alasan utama penyebab tingginya ketidakpatuhan masyarakat dalam memenuhi ketentuan 5M yang telah ditetapkan Pemerintah, seperti: 
memakai masker, menjaga jarak (social distancing), mencuci tangan, menghindari kerumunan, dan mengurangi mobilitas.

Banyaknya masyarakat yang belum menerapkan protokol kesehatan dalam menjalankan aktivitas sehari-hari, merupakan fenomena tersendiri yang patut mendapatkan perhatian serius dari berbagai pihak termasuk unsur Kepolisian didalamnya. Hal ini dimungkinkan mengingat pelaksanaan fungsi dan tugas pokok Kepolisian di bidang Kamtibmas yang dapat menjangkau hingga unit-unit terkecil dalam masyarakat melalui pengimplementasian strategi Pemolisian Masyarakat (Polmas).

Keberadaan Bhabinkamtibmas sebagai Pengemban Pemolisian Masyarakat (Polmas) diharapkan mampu menjadi pionir terdepan dalam upaya melakukan pemberdayaan terhadap segenap komponen dan sumber daya masyarakat dalam rangka penanggulangan Covid-19 melalui penerapan protokol kesehatan secara optimal mulai dari lingkupnya yang paling kecil, yaitu individu, keluarga sampai dengan lingkungan masyarakat dalam skala yang lebih luas.

Melalui pelaksanaan strategi Pemolisian Masyarakat (Polmas) yang berbasis pada optimalisasi pelaksanaan fungsi dan tugas pokok Kepolisian di bidang Kamtibmas, Polri diharapkan mampu mendukung penerapan protokol kesehatan selama pandemi Covid-19 dalam rangka terwujudnya situasi Kamtibmas yang kondusif.

\section{IDENTIFIKASI MASALAH}

Mengacu pada uraian latar belakang seperti tersebut di atas, maka dalam pembahasan mengenai materi dan substansi penelitian ini selanjutnya akan dibatasi pada rumusan masalah sebagai berikut:

1. Bagaimana fungsi dan tugas pokok Kepolisian berdasarkan Undang-Undang Nomor 2 Tahun 2002 tentang Kepolisian Negara Republik Indonesia?

2. Bagaimana strategi Pemolisian Masyarakat (Polmas) berdasarkan Peraturan Kapolri Nomor 3 Tahun 2015 tentang Pemolisian Masyarakat (Polmas)?

3. Bagaimana pelaksanaan fungsi dan tugas pokok Bhabinkamtibmas sebagai Pengemban Pemolisian Masyarakat (Polmas) yang dapat mendukung penerapan protokol kesehatan selama pandemi Covid-19 dalam rangka terwujudnya situasi Kamtibmas yang kondusif? 


\section{METODE}

Penelitian ini menggunakan metode penelitian yuridis normatif, yaitu mendalami kaidah atau aturan hukum sebagai sistem yang terkait dengan peristiwa hukum tertentu. Bahan Hukum Tersier, Bahan Hukum Sekunder dan Bahan Hukum Tersier yang diperoleh dari buku-buku, literatur, makalah hingga perundang-undangan digunakan sebagai Data Sekunder dalam penelitian.

\section{HASIL DAN PEMBAHASAN}

\section{A. Dasar Hukum Penyelenggaraan}

1. Undang-Undang Nomor 2 Tahun 2002 tentang Kepolisian Negara Republik Indonesia;

2. Peraturan Pemerintah Nomor 21 Tahun 2020 tentang Pembatasan Sosial Berskala Besar dalam rangka Percepatan Penanganan Corona Virus Disease 2019 (Covid-19);

3. Instruksi Presiden Nomor 6 Tahun 2020 tentang Peningkatan Disiplin dan Penegakan Hukum Protokol Kesehatan dalam Pencegahan dan Pengendalian Corona Virus Disease 2019;

4. Peraturan Menteri Kesehatan Nomor 9 Tahun 2020 tentang Pedoman Pembatasan Sosial Berskala Besar dalam rangka Percepatan Penanganan Corona Virus Disease 2019 (Covid-19);

5. Peraturan Kapolri Nomor 3 Tahun 2015 tentang Pemolisian Masyarakat.

\section{B. Fungsi dan Tugas Pokok Kepolisian}

Kepolisian Negara Republik Indonesia merupakan alat negara yang berperan dalam memelihara keamanan dan ketertiban masyarakat, menegakkan hukum, serta memberikan perlindungan, pengayoman, dan pelayanan kepada masyarakat dalam rangka terpeliharanya keamanan dalam negeri.

Barda Nawawi Arief mengungkapkan bahwa Polri dalam menjalankan tugasnya berperan ganda baik sebagai penegak hukum maupun sebagai pekerja sosial (social worker) pada aspek sosial dan kemasyarakatan (pelayanan dan 
pengabdian $)^{1}$. Penegakan hukum mensyaratkan polisi harus berdiri di atas peraturan hukum. Pada sisi lain polisi juga mengemban tugas sosial kemasyarakatan dimana harus memperhatikan nilai-nilai yang hidup di masyarakat ${ }^{2}$.

Fungsi Kepolisian menurut Pasal 2 Undang-Undang Nomor 2 Tahun 2002 tentang Kepolisian Negara Republik Indonesia adalah:

Fungsi kepolisian adalah salah satu fungsi pemerintahan negara di bidang pemeliharaan keamanan dan ketertiban masyarakat, penegakan hukum, perlindungan, pengayoman, dan pelayanan kepada masyarakat.

Fungsi Kepolisian yang menyelenggarakan keamanan dan ketertiban masyarakat, penegakan hukum, perlindungan, pengayoman dan pelayanan kepada masyarakat, tertuju pada pemeliharaaan dan menjaga tetap berlakunya dan ditaatinya norma-norma yang ada di masyarakat tersebut, sehingga kehidupan dalam masyarakat menjadi aman, tenteram, tertib, damai dan sejahtera ${ }^{3}$.

Adapun tugas pokok Kepolisian diatur dalam Pasal 13 Undang-Undang Nomor 2 Tahun 2002 tentang Kepolisian Negara Republik Indonesia, yaitu:

Tugas pokok Kepolisian Negara Republik adalah:

a. memelihara keamanan dan ketertiban masyarakat;

b. menegakkan hukum; dan

c. memberikan perlindungan, pengayoman, dan pelayanan kepada masyarakat.

Tugas pokok Kepolisian mendapatkan penjabaran lebih lanjut dalam Pasal 14 ayat (1) Undang-Undang Nomor 2 Tahun 2002 tentang Kepolisian Negara Republik Indonesia yang menyatakan bahwa:

Dalam melaksanakan tugas pokok sebagaimana dimaksud dalam Pasal 13, Kepolisian Negara Republik Indonesia bertugas :

a. melaksanakan pengaturan, penjagaan, pengawalan, dan patroli terhadap kegiatan masyarakat dan pemerintah sesuai kebutuhan;

b. menyelenggarakan segala kegiatan dalam menjamin keamanan, ketertiban, dan kelancaran lalu lintas di jalan;

1 Kasman Tasaripa, Tugas dan Fungsi Kepolisian dalam Perannya sebagai Penegak Hukum menurut Undang-Undang Nomor 2 Tahun 2002 tentang Kepolisian, Jurnal Ilmu Hukum Legal Opinion, Edisi 2, Volume 1, Tahun 2013.

2 Riyanto Ulil Ashar dan Joko Setiyono, Tugas dan Fungsi Polisi sebagai Penegak Hukum dalam Perspektif Pancasila, Jurnal Pembangunan Hukum Indonesia, Volume 2, Nomor 3, Tahun 2020, hlm. 362.

3 I Ketut Adi Purnama, Hukum Kepolisian; Sejarah dan Peranan Polri dalam Penegakan Hukum serta Perlindungan HAM, Refika Aditama, Bandung, 2018, hlm. 63. 
c. membina masyarakat untuk meningkatkan partisipasi masyarakat, kesadaran hukum masyarakat serta ketaatan warga masyarakat terhadap hukum dan peraturan perundang-undangan;

d. turut serta dalam pembinaan hukum nasional;

e. memelihara ketertiban dan menjamin keamanan umum;

f. melakukan koordinasi, pengawasan, dan pembinaan teknis terhadap kepolisian khusus, penyidik pegawai negeri sipil, dan bentuk-bentuk pengamanan swakarsa;

g. melakukan penyelidikan dan penyidikan terhadap semua tindak pidana sesuai dengan hukum acara pidana dan peraturan perundang-undangan lainnya;

h. menyelenggarakan identifikasi kepolisian, kedokteran kepolisian, laboratorium forensik dan psikologi kepolisian untuk kepentingan tugas kepolisian;

i. melindungi keselamatan jiwa raga, harta benda, masyarakat, dan lingkungan hidup dari gangguan ketertiban dan/atau bencana termasuk memberikan bantuan dan pertolongan dengan menjunjung tinggi hak asasi manusia;

j. $\quad$ melayani kepentingan warga masyarakat untuk sementara sebelum ditangani oleh instansi dan/atau pihak yang berwenang;

k. memberikan pelayanan kepada masyarakat sesuai dengan kepentingannya dalam lingkup tugas kepolisian; serta

l. melaksanakan tugas lain sesuai dengan peraturan perundangundangan.

\section{Strategi Pemolisian Masyarakat (Polmas)}

Pengertian Pemolisian Masyarakat menurut Pasal 1 angka 2 Peraturan Kapolri Nomor 3 Tahun 2015 tentang Pemolisian Masyarakat adalah:

Pemolisian Masyarakat (Community Policing) yang selanjutnya disingkat Polmas adalah suatu kegiatan untuk mengajak masyarakat melalui kemitraan anggota Polri dan masyarakat, sehingga mampu mendeteksi dan mengidentifikasi permasalahan Keamanan dan Ketertiban Masyarakat (Kamtibmas) di lingkungan serta menemukan pemecahan masalahnya.

Community Policing diterjemahkan sebagai Pemolisian masyarakat atau Perpolisian masyarakat atau disingkat Polmas. Policing dapat diartikan sebagai perpolisian yaitu segala hal ikhwal tentang penyelenggaraan fungsi kepolisian, tidak hanya menyangkut operasionalisasi (taktik/teknik) fungsi kepolisian tetapi juga pengelolaan fungsi kepolisian secara menyeluruh mulai dari tataran manajemen puncak sampai dengan manajemen lapis bawah, termasuk pemikiran filsafati yang melatarbelakanginya atau pemolisian yaitu pemberdayaan segenap komponen dan segala sumber daya yang dapat dilibatkan dalam pelaksanaan tugas 
atau fungsi kepolisian agar mendapat hasil yang lebih optimal. Community diterjemahkan komunitas dapat diartikan sebagai sekelompok warga atau komunitas yang berada di dalam suatu wilayah kecil yang jelas batas-batasnya, batas wilayah komunitas dapat berbentuk RT, RW, Desa, Kelurahan ${ }^{4}$.

Polmas adalah penyelenggaraan tugas kepolisian yang mendasari kepada pemahaman bahwa untuk menciptakan kondisi aman dan tertib tidak mungkin dilakukan oleh Polri sepihak sebagai subjek dan masyarakat sebagai objek. Oleh karena itu dalam upaya menciptakan keamanan dan ketertiban ini harus dilakukan bersama oleh Polisi dan masyarakat, dengan cara memberdayakan masyarakat melalui kemitraan Polisi dan warga masyarakat ${ }^{5}$.

Polmas merupakan suatu model strategi perpolisian yang menegaskan kemitraan yang sejajar atau setara antara polisi dengan masyarakat, dalam menyelesaikan dan mengatasi setiap permasalahan sosial yang mengancam keamanan dan ketertiban yang berfungsi sebagai meningkatkan kualitas hidup masyarakat setempat. Dalam hal ini, masyarakat turut diberdayakan sehingga tidak ada lagi opini yang semata-mata warga sebagai objek dalam penyelenggaraan fungsi kepolisian, melainkan masyarakat sebagai suatu subyek yang menentukan upaya penciptaan dan pengelolaan lingkungan yang aman dan tertib dengan difasilitasi oleh petugas kepolisian. Masyarakat dan polisi berusaha menemukan, mengidentifikasi, menganalisis hingga mencari jalan keluar atas masalah gangguan keamanan dan ketertiban ${ }^{6}$.

\section{Bhabinkamtibmas sebagai Pengemban Pemolisian Masyarakat (Polmas)}

Pengemban Polmas berdasarkan Pasal 1 angka 3 Peraturan Kapolri Nomor 3 Tahun 2015 tentang Pemolisian Masyarakat adalah setiap anggota Polri yang melaksanakan Polmas di masyarakat atau komunitas. Sedangkan khusus mengenai Pengemban Polmas di Desa/Kelurahan menurut Pasal 1 angka 4 Peraturan Kapolri Peraturan Kapolri Nomor 3 Tahun 2015 tentang Pemolisian Masyarakat adalah

\footnotetext{
4 Muh. Aswin dan Junadi, Peran Serta Masyarakat dalam Membantu Kepolisian demi Menjaga Keamanan Wilayah Kota Makasar, Alauddin Law Development Journal (ALDEV), Volume 2, Nomor 3, November 2020, hlm. 457.

5 Siti Marwiyah, Model Pemolisian Masyarakat sebagai Upaya Penanggulangan Pembalakan Hutan, Jurnal Yustisia, Volume 3, Nomor 1, Januari-April 2014, hlm. 64.

${ }^{6}$ Eddy Rifai, Model Pelaksanaan Pemolisian Masyarakat (Polmas) oleh FKPM dalam Menciptakan Kamtibmas di Kota Bandar Lampung, Jurnal Cepalo Volume 2, Nomor 1, Januari-Juni 2018, hlm. 45.
} 
Bhayangkara Pembina Keamanan dan Ketertiban Masyarakat yang selanjutnya disebut Bhabinkamtibmas.

Fungsi Bhabinkamtibmas berdasarkan Pasal 26 ayat (1) Peraturan

Kapolri Nomor 3 Tahun 2015 tentang Pemolisian Masyarakat adalah:

a. melaksanakan kunjungan/sambang kepada masyarakat untuk:

1. mendengarkan keluhan warga masyarakat tentang permasalahan Kamtibmas dan memberikan penjelasan serta penyelesaiannya;

2. memelihara hubungan silaturahmi/persaudaraan;

b. membimbing dan menyuluh di bidang hukum dan Kamtibmas untuk meningkatkan kesadaran hukum dan Kamtibmas dengan menjunjung tinggi Hak Asasi Manusia (HAM);

c. menyebarluaskan informasi tentang kebijakan pimpinan Polri berkaitan dengan Pemeliharaan Keamanan dan Ketertiban Masyarakat (Harkamtibmas);

d. mendorong pelaksanaan siskamling dalam pengamanan lingkungan dan kegiatan masyarakat;

e. memberikan pelayanan kepolisian kepada masyarakat yang memerlukan;

f. menggerakkan kegiatan masyarakat yang bersifat positif;

g. mengkoordinasikan upaya pembinaan Kamtibmas dengan perangkat desa/kelurahan dan pihak-pihak terkait lainnya;

h. melaksanakan konsultasi, mediasi, negosiasi, fasilitasi, motivasi kepada masyarakat dalam Harkamtibmas dan pemecahan masalah kejahatan dan sosial.

Adapun tugas pokok Bhabinkamtibmas menurut Pasal 27 Peraturan Kapolri Nomor 3 Tahun 2015 tentang Pemolisian Masyarakat adalah:

(1) tugas pokok Bhabinkamtibmas melakukan pembinaan masyarakat, deteksi dini dan mediasi/negosiasi agar tercipta kondisi yang kondusif di desa/kelurahan.

(2) dalam melaksanakan tugas pokok, sebagaimana dimaksud ayat (1) Bhabinkamtibmas melakukan kegiatan:

a. kunjungan dari rumah ke rumah (door to door) pada seluruh wilayah penugasannya;

b. melakukan dan membantu pemecahan masalah (problem solving);

c. melakukan pengaturan dan pengamanan kegiatan masyarakat;

d. menerima informasi terjadinya tindak pidana;

e. memberikan perlindungan sementara kepada orang yang tersesat, korban kejahatan dan pelanggaran;

f. ikut serta dalam memberikan bantuan kepada korban bencana alam dan wabah penyakit;

g. memberikan bimbingan dan petunjuk kepada masyarakat atau komunitas berkaitan dengan permasalahan Kamtibmas dan pelayanan Polri. 


\section{E. Kondisi Saat Ini}

Kasus penularan Covid-19 di Indonesia masih menunjukkan angka yang terus naik. Hingga 28 Januari 2021 tercatat jumlah kasus positif sebanyak 1.037.993 jiwa, sembuh 842.122 jiwa, dan meninggal dunia 29.331 jiwa. Sementara secara global WHO mencatat, dari 223 negara jumlah kasus terkonfirmasi sebanyak 100.455.529 jiwa dan meninggal dunia 2.166.440 jiwa ${ }^{7}$.

Kebijakan Pemerintah dalam upaya penanggulangan Covid-19 melalui pemberlakuan Peraturan Pemerintah Nomor 21 Tahun 2020 tentang Pembatasan Sosial Berskala Besar (PSBB), Instruksi Presiden Nomor 6 Tahun 2020 tentang Peningkatan Disiplin dan Penegakan Hukum Protokol Kesehatan dalam Pencegahan dan Pengendalian Corona Virus Disease 2019, serta program kebijakan serupa lainnya yang berlaku pada beberapa daerah Provinsi dan Kabupaten/Kota, nyatanya belum memberikan hasil yang optimal guna membatasi pola penyebaran Covid-19 sebagaimana yang diharapkan.

Sementara itu, tingkat kepatuhan masyarakat dalam penerapan protokol kesehatan pun terus mengalami penurunan. Wiku Adisasmito, selaku Juru Bicara Satgas Penanganan Covid-19 mengungkapkan adanya penurunan kepatuhan dalam menjalankan protokol kesehatan selama November 2020. Adapun protokol kesehatan yang dimaksud, yakni memakai masker, mencuci tangan dengan sabun dan air mengalir, serta menjaga jarak (3M). Wiku menyatakan angka kepatuhan masyarakat menggunakan masker sebesar 59,32 persen dan menjaga jarak 43,46 persen. Padahal untuk menurunkan angka kasus Covid-19 dibutuhkan kepatuhan dari 75 persen populasi penduduk. Bahkan menurutnya, dari 512 kabupaten/kota, hanya kurang dari 9 kabupaten/kota yang patuh menjalankan protokol kesehatan ${ }^{8}$.

Dukungan Kepolisian guna mengawal kebijakan Pemerintah dalam rangka penerapan protokol kesehatan sesungguhnya telah ditandai dengan terbitnya Maklumat Kapolri Nomor Mak/2/III/2020 tentang Kepatuhan terhadap Kebijakan

\footnotetext{
7 Satuan Tugas Penanganan Covid-19, Data Sebaran, melalui https://covid19.go.id/, diakses pada tanggal 29 Januari 2021

8 Tita Meydhalifah, Mengapa Kepatuhan Masyarakat terhadap Protokol Kesehatan Kian Menurun, 4 Desember 2020, melalui https://www.kompas.com/tren/read/2020/12/04/161905465/mengapa-kepatuhanmasyarakat-terhadap-protokol-kesehatan-kian-menurun?page=all, diakses pada 28 Januari 2021.
} 
Pemerintah dalam Penanganan Virus Corona tanggal 19 Maret 2020 ${ }^{9}$. Ringkasnya, isi maklumat Kapolri adalah Polri akan menindak masyarakat yang masih berkerumun, menimbun kebutuhan bahan pokok maupun kebutuhan masyarakat lainnya secara berlebihan dan menyebarkan berita hoaks. Selain itu, Polri juga akan melakukan penindakan terhadap berbagai tindakan kriminalitas yang disebabkan karena pandemi seperti pencurian, perampokan, penjarahan dan tindakan kriminalitas dengan motif ekonomi lainnya. Langkah tersebut wujud dukungan Polri kepada Pemerintah terkait penanganan Covid-19 dan memutus mata rantai pandemi corona di Indonesia melalui penegakan hukum kepada masyarakat ${ }^{10}$.

Meskipun maklumat tersebut kemudian dicabut melalui Surat Telegram Rahasia (TR) Kapolri Nomor STR/364/VI/OPS.2./2020 tentang Perintah kepada Jajaran mengenai Pencabutan Maklumat Kapolri dan Upaya Mendukung Kebijakan Adaptasi Baru (New Normal) pada tanggal 25 Juni 202011, namun dirasakan telah memberikan andil dan dukungan yang konkrit terhadap upaya penanggulangan Covid-19 di tengah-tengah masyarakat.

\section{F. Faktor-Faktor yang Mempengaruhi}

Beberapa faktor yang mempengaruhi terjadinya penurunan tingkat disiplin masyarakat dalam menerapkan protokol kesehatan yaitu:

\section{a. Faktor Internal}

Merupakan faktor-faktor intern yang berasal dari dalam individu yang mempengaruhi tingkat keasadaran dan kepatuhan dalam menerapkan protokol kesehatan, antara lain:

a. Ketidakpercayaan mengenai keberadaan Covid-19;

b. Kurangnya pemahaman mengenai bahaya Covid-19;

c. Kurangnya pemahaman mengenai rentannya penyebaran Covid-19;

9 Bayu Hermawan, Kapolri Keluarkan Maklumat Ikuti Pemerintah Cegah Covid-19, 22 Maret 2020, melalui https://republika.co.id/berita/q7jygt354/kapolri-keluarkan-maklumat-ikuti-pemerintah-cegah-covid19, diakses pada 28 Januari 2021.

${ }^{10}$ Dona Budi Kharisma, Format Kepolisian di Masa Pandemi, Jurnal Rechtsvinding Online, BPHN, 7 Desember 2020, hlm. 1.

${ }^{11}$ Devina Halim, Adaptasi New Normal, Kapolri Cabut Maklumat, 26 Juni 2020, melalui https:// nasional.kompas.com/read/2020/06/26/12395951/adaptasi-new-normal-kapolri-cabut-maklumat?page=all, diakses pada 28 Januari 2021. 
d. Kurangnya pemahaman mengenai pentingnya dan manfaat penerapan protokol kesehatan; dan

e. Tingkat kejenuhan masyarakat.

\section{b. Faktor Eksternal}

Merupakan faktor-faktor ekstern yang berasal dari luar individu yang mempengaruhi tingkat keasadaran dan kepatuhan dalam menerapkan protokol kesehatan, antara lain:

a. Kurangnya sosialisasi, edukasi dan informasi mengenai Covid-19;

b. Kesimpangsiuran informasi dan berita bohong (hoaks) mengenai Covid-19;

c. Kurangnya ketersediaan fasilitas protokol kesehatan, seperti masker, sabun, dan hand sanitizer yang disiapkan pada area publik;

d. Kelonggaran penegakkan disiplin dalam pelanggaran penerapan protokol kesehatan; dan

e. Kelonggaran penegakkan hukum dalam pelanggaran penerapan protokol kesehatan.

\section{c. Kondisi yang Diharapkan}

Kondisi yang diharapkan melalui optimalisasi strategi Pemolisian Masyarakat (Polmas) guna mendukung penerapan protokol kesehatan selama pandemi Covid-19 dalam rangka terwujudnya situasi Kamtibmas yang kondusif, antara lain:

1. Terwujudnya keikutsertaan dan partisipasi masyarakat dalam pelaksanaan kebijakan penanggulangan Covid-19 secara umum;

2. Terlaksananya kegiatan pembinaan yang bertujuan untuk meningkatkan kesadaran dan kepatuhan masyarakat dalam penerapan protokol kesehatan;

3. Terintegrasinya penyebarluasan informasi, sosialisasi dan edukasi mengenai penerapan protokol kesehatan kepada masyarakat secara baik dan benar;

4. Terselenggaranya koordinasi dan kerjasama lintas sektoral yang melibatkan partisipasi masyarakat dalam pelaksanaan pemantauan, pengawasan, dan pendisiplinan penerapan protokol kesehatan; dan

5. Terwujudnya efektiifitas penegakan hukum yang bersifat pre-emptif, preventif, dan represif dalam pelanggaran penerapan protokol kesehatan. 


\section{d. Pemecahan Masalah}

Mempertimbangkan kondisi terkini penerapan protokol kesehatan yang terus mengalami penurunan di tengah masyarakat, kiranya penting bagi Polri untuk melakukan pemecahan masalah melalui penguatan pelaksanaan fungsi dan tugas pokok Kepolisian yang diarahkan pada upaya guna mendukung penerapan protokol kesehatan dalam rangka terwujudnya situasi Kamtibmas yang kondusif.

Penguatan pelaksanaan fungsi dan tugas pokok Kepolisian sebagaimana dimaksud, diantaranya dengan melakukan optimalisasi strategi Pemolisian Masyarakat (Polmas) melalui penyesuaian terhadap pelaksanaan fungsi dan tugas pokok Bhabinkamtibmas sebagai Pengemban Pemolisian Masyarakat (Polmas) yang berorientasi pada tercapainya peningkatan kesadaran dan kepatuhan masyarakat dalam menerapkan protokol kesehatan.

1. Peraturan

Pemerintah No. 21

Tahun 2020 juncto.

2. Instruksi Presiden No. 6 Tahun 2020

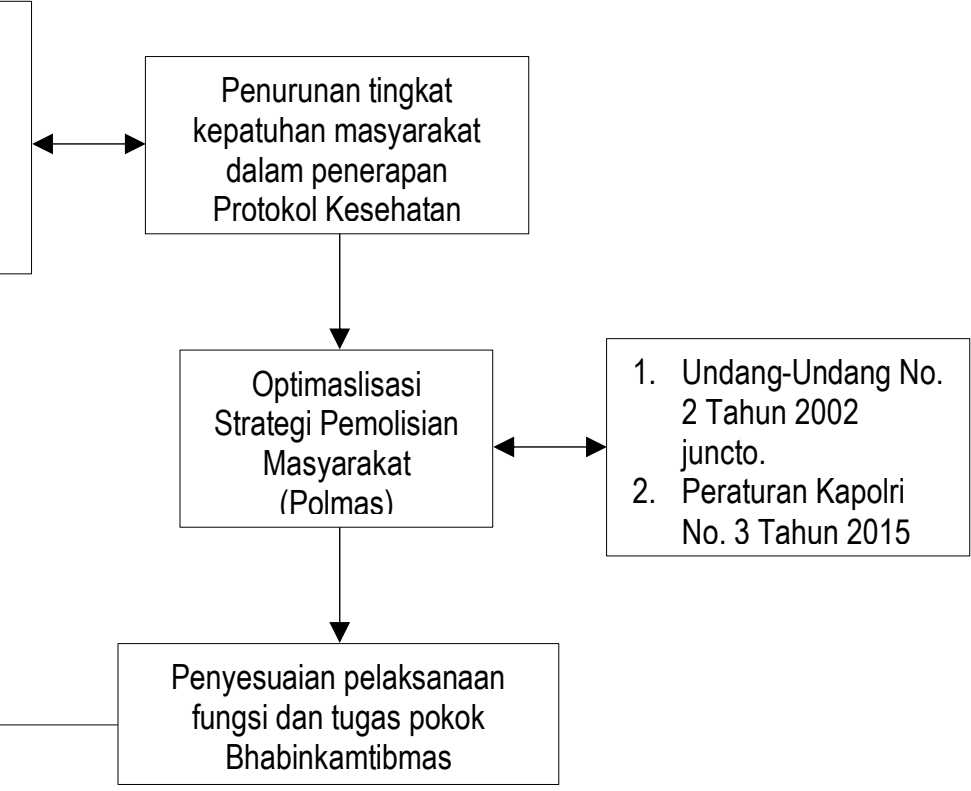

Apabila merujuk pada Instruksi Presiden Nomor 6 Tahun 2020 tentang Peningkatan Disiplin dan Penegakan Hukum Protokol Kesehatan dalam Pencegahan dan Pengendalian Corona Virus Disease 2019, maka pelaksanaannya pertama-tama akan diarahkan terlebih dahulu pada langkah-langkah sebagai berikut: 
1. Memberikan dukungan kepada gubernur, bupati/walikota dengan mengerahkan kekuatan Kepolisian Negara Republik Indonesia untuk melakukan pengawasan pelaksanaan protokol kesehatan di masyarakat;

2. Bersama Panglima Tentara Nasional Indonesia dan instansi lain secara terpadu dengan pemerintah daerah menggiatkan patroli penerapan protokol kesehatan di masyarakat;

3. Melakukan pembinaan masyarakat untuk berpartisipasi dalam upaya pencegahan dan pengendalian Corona Virus Disease 2019 (Covid-19); dan

4. Mengefektifkan upaya penegakan hukum terhadap pelanggaran protokol kesehatan.

Langkah-langkah sebagaimana tersebut di atas, secara teknis dapat dilakukan melalui serangkaian kegiatan dalam bentuk:

1. Pengawasan dan pendisiplinan kepada masyarakat untuk tetap mematuhi protokol kesehatan seperti memakai masker, menjaga jarak (social distancing), mencuci tangan, menghindari kerumunan, dan mengurangi mobilitas;

2. Meningkatkan kerjasama lintas sektoral dalam upaya pencegahan Covid-19;

3. Melaksanakan sosialisasi dan edukasi secara terus menerus bersama stakeholder untuk memberikan pemahaman yang benar kepada masyarakat;

4. Melaksanakan koordinasi secara intensif dengan Gugus Tugas Penanganan Covid-19 di daerah; dan

5. Melaksanakan pembatasan kegiatan masyarakat pada daerah-daerah yang masih menerapkan Pembatasan Sosial Berskala Besar (PSBB) atau pada daerah yang masih dalam kategori oranye dan merah sesuai dengan ketentuan yang berlaku.

Khusus mengenai penyesuaian terhadap pelaksanaan fungsi dan tugas pokok Bhabinkamtibmas sebagai Pengemban Pemolisian Masyarakat (Polmas) yang berorientasi pada tercapainya peningkatan kesadaran dan kepatuhan masyarakat dalam penerapan protokol kesehatan, maka pelaksanaannya dilakukan dengan dukungan dan keterlibatan Forum Kemitraan Polri dan Masyarakat (FKPM) melalui strategi: 
a. kemitraan dan kerjasama dengan masyarakat atau komunitas;

b. pemecahan masalah;

c. pembinaan keamanan swakarsa;

d. penitipan eksistensi FKPM ke dalam pranata masyarakat tradisonal;

e. pendekatan pelayanan Polri kepada masyarakat;

f. bimbingan dan penyuluhan;

g. patroli dialogis;

h. intensifikasi hubungan Polri dengan komunitas;

i. koordinasi, pengawasan, dan pembinaan teknis Kepolisian; dan

j. kerjasama bidang Kamtibmas.

Adapun beberapa kegiatan yang dapat dilaksanakan antara lain:

1. melaksanakan kunjungan/sambang dari rumah ke rumah (door to door system) untuk mendengarkan keluhan warga mengenai permasalahan penerapan protokol kesehatan, memberikan penjelasan termasuk membantu pemecahan masalah dan mengupayakan penyelesaiannya (problem solving);

2. melakukan pembimbingan, edukasi dan penyuluhan mengenai pentingnya peningkatan kesadaran dan kepatuhan dalam penerapan protokol kesehatan yang dilaksanakan pada kantor pemerintahan desa/kelurahan, balai pertemuan warga atau fasilitas umum lainnya yang dapat menjangkau masyarakat secara umum;

3. melaksanakan konsultasi, mediasi, negosiasi, fasilitasi, motivasi dalam pemecahan masalah penerapan protokol kesehatan bersama-sama dengan unsur pemerintah desa/kelurahan, tokoh masyarakat, dan komunitas masyarakat lainnya;

4. menyebarluaskan informasi dan sosialisasi mengenai kebijakan Pemerintah, pimpinan Polri, himbauan atau iklan layanan masyarakat yang berkaitan dengan penerapan protokol kesehatan secara massif melalui pemanfaatan website Polri, media sosial, fasilitas audio video pada kantor-kantor Kepolisian terdekat, traffic light atau media lainnya yang memungkinkan untuk itu; 
5. mendorong pemantauan, pengawasan dan pendisiplinan penerapan protokol kesehatan dalam pengamanan lingkungan dan kegiatan masyarakat, melalui kegiatan patroli yang digelar secara rutin pada wilayah-wilayah rawan yang berpotensi menimbulkan kerumunan atau area lainnya yang ditetapkan oleh Gugus Tugas Percepatan Penanganan Covid-19 di daerah;

6. memberikan perlindungan dan bantuan pelayanan kepada masyarakat melalui Pemanfaatan sambungan langsung Call Centre 110, National Traffic Management Centre (NTMC), dan Traffic Management Centre (TMC) Polri, fasilitas kesehatan, rumah sakit rujukan atau Hotline 119 Satuan Tugas Penanganan Covid-19; dan

7. melakukan deteksi dini, menerima informasi, penindakan disiplin, dan penegakan hukum terjadinya pelanggaran penerapan protokol kesehatan bersama-sama dengan instansi atasan dan unsur terkait lainnya dengan tetap mengutamakan pendekatan persuasif dan humanis.

\section{PENUTUP}

\section{A. Simpulan}

Dari uraian diatas dapatlah dikemukakan bahwa beberapa kesimpulan antara lain sebagaui berikut:

1. Fungsi dan tugas pokok Kepolisian berdasarkan Undang-Undang Nomor 2 Tahun 2002 tentang Kepolisian Negara Republik Indonesia merupakan salah satu fungsi pemerintahan dalam rangka memelihara keamanan, menegakkan hukum, memberikan perlindungan, pengayoman, dan pelayanan kepada masyarakat dalam rangka terpeliharanya keamanan dalam negeri. Tugas ini dilaksanakan oleh Polri melalui berbagai peraturan pelaksanaannya termasuk Peraturan Kapolri Nomor 3 Tahun 2015 tentang Pemolisian Masyarakat (Polmas) yang melandasi hubungan kerjasama dan kemitraan antara Polri dan masyarakat dalam rangka mewujudkan situasi Keamanan dan Ketertiban Masayarakat (Kamtibmas).

2. Strategi Pemolisian masyarakat (Polmas) berdasarkan Peraturan Kapolri Nomor 3 Tahun 2015 tentang Pemolisian Masyarakat (Polmas) merupakan model strategi yang melandasi hubungan kerjasama dan kemitraan yang sejajar antara Polri dan masyarakat dalam menyelesaikan dan mengatasi setiap permasalahan sosial yang 
mengancam keamanan dan ketertiban masyarakat (Kamtibmas). Strategi ini dilaksanakan dengan melakukan pemberdayaan terhadap segenap komponen dan segala sumber daya yang dapat mendukung pelaksanaan fungsi dan tugas Kepolisian.

3. Pelaksanaan fungsi dan tugas pokok Bhabinkamtibmas sebagai Pengemban Pemolisian Masyarakat (Polmas) yang dapat mendukung penerapan protokol kesehatan selama pandemi Covid-19 dalam rangka terwujudnya situasi Kamtibmas yang kondusif, utamanya diarahkan melalui serangkaian kegiatan dalam bentuk pembinaan, pemantauan, pengawasan, penindakan, dan penegakan hukum yang bersifat pre-emtif, preventif, dan represif dengan cara-cara persuasif dan humanis selaras dengan Instruksi Presiden Nomor 6 Tahun 2020 tentang Peningkatan Disiplin dan Penegakan Hukum Protokol Kesehatan dalam Pencegahan dan Pengendalian Corona Virus Disease 2019.

\section{B. Saran}

1. Pemerintah seyogyanya dapat mengalokasikan ketersediaan anggaran dan fasilitas yang cukup guna menunjang pelaksanaan fungsi dan tugas pokok Kepolisian dalam rangka meningkatkan kesadaran dan kepatuhan penerapan protokol kesehatan selama berlangsungnya pandemi Covid-19 dalam rangka terwujudnya situasi Kamtibmas yang kondusif sesuai dengan Instruksi Presiden Nomor 6 Tahun 2020 tentang Peningkatan Disiplin dan Penegakan Hukum Protokol Kesehatan dalam Pencegahan dan Pengendalian Corona Virus Disease 2019.

2. Pelaksanaan fungsi dan tugas pokok Bhabinkamtibmas selama berlangsungnya pandemi Covid-19 sedapat mungkin disesuaikan dan diarahkan pada serangkaian kegiatan yang mampu menunjang peningkatan kesadaran dan kepatuhan masyarakat dalam menerapkan protokol kesehatan berdasarkan program dan kebijakan Pemerintah dalam rangka pencegahan dan penanggulangan Covid-19.

3. Menyusul pencabutan Maklumat Kapolri Nomor Mak/2/III/2020 tentang Kepatuhan terhadap Kebijakan Pemerintah dalam Penanganan Virus Corona, hendaknya segera diupayakan adanya ketentuan serupa yang berlaku sebagai rujukan dan pedoman untuk melaksanakan penindakan disiplin dan penegakan 
hukum terhadap pelanggaran penerapan protokol kesehatan dalam rangka terwujudnya situasi Kamtibmas yang kondusif.

\section{DAFTAR PUSTAKA}

\section{A. Buku}

I Ketut Adi Purnama, Hukum Kepolisian; Sejarah dan Peranan Polri dalam Penegakan Hukum serta Perlindungan HAM, Refika Aditama, Bandung, 2018, hlm. 63.

\section{B. Jurnal:}

Eddy Rifai, Model Pelaksanaan Pemolisian Masyarakat (Polmas) oleh FKPM dalam Menciptakan Kamtibmas di Kota Bandar Lampung, Jurnal Cepalo Volume 2, Nomor 1, Januari-Juni 2018, hlm. 45.

Kasman Tasaripa, Tugas dan Fungsi Kepolisian dalam Perannya sebagai Penegak Hukum menurut Undang-Undang Nomor 2 Tahun 2002 tentang Kepolisian, Jurnal Ilmu Hukum Legal Opinion, Edisi 2, Volume 1, Tahun 2013.

Muh. Aswin dan Junadi, Peran Serta Masyarakat dalam Membantu Kepolisian demi Menjaga Keamanan Wilayah Kota Makasar, Alauddin Law Development Journal (ALDEV), Volume 2, Nomor 3, November 2020, hlm. 457.

Riyanto Ulil Ashar dan Joko Setiyono, Tugas dan Fungsi Polisi sebagai Penegak Hukum dalam Perspektif Pancasila, Jurnal Pembangunan Hukum Indonesia, Volume 2, Nomor 3, Tahun 2020, hlm. 362.

Siti Marwiyah, Model Pemolisian Masyarakat sebagai Upaya Penanggulangan Pembalakan Hutan, Jurnal Yustisia, Volume 3, Nomor 1, Januari-April 2014, hlm. 64.

\section{Sumber Lain:}

Bayu Hermawan, Kapolri Keluarkan Maklumat Ikuti Pemerintah Cegah Covid-19, 22 Maret 2020, melalui https://republika.co.id/berita/q7jygt354/kapolrikeluarkan-maklumat-ikuti-pemerintah-cegah-covid19, diakses pada 28 Januari 2021. 
Jl. Ir. H. Djuanda KM. 03 Indramayu 45213 Telp. 0234-275599 Email: yustitia.fh@unwir.ac.id

Devina Halim, Adaptasi New Normal, Kapolri Cabut Maklumat, 26 Juni 2020, melalui https://nasional.kompas.com/read/2020/06/26/12395951/adaptasi-newnormal-kapolri-cabut-maklumat?page=all, diakses pada 28 Januari 2021

Dona Budi Kharisma, Format Kepolisian di Masa Pandemi, Jurnal Rechtsvinding Online, BPHN, 7 Desember 2020, hlm. 1.

Satuan Tugas Penanganan Covid-19, Data Sebaran, melalui https://covid19.go.id/, diakses pada tanggal 29 Januari 2021.

Tita Meydhalifah, Mengapa Kepatuhan Masyarakat terhadap Protokol Kesehatan Kian Menurun, 4 Desember 2020, melalui https://www.kompas.com/tren/read/2020/12/04/161905465/mengapakepatuhan-masyarakat-terhadap-protokol-kesehatan-kian-

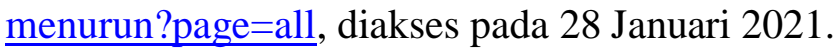

